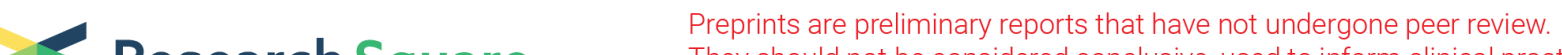 \\ Research Square They should not be considered conclusive, used to inform clinical practice, or referenced by the media as validated information.
}

\section{Mesenchymal Stem Cell Transplantation in Patients With Acute Myocardial Infarction: A Systematic Review and Meta-Analysis of Randomized Controlled Trials}

Jiang Yu

Southwest medical university

Runfeng Zhang ( $0905189082 @ q q . c o m$ )

The Third Hospital of Miangyang/ Sichuan Mental Health Centre

Yi-li Mao

The Third Hospital of Mianyang/Sichuan Mental Health Centre

Heng Zhang

The Third Hospital of Mianyang/Sichuan Mental Health Centre

\section{Research Article}

Keywords: Acute myocardial infarction (AMI), Cell therapy, Mesenchymal Stem Cells (MSCs), transplantation timing, cell doses, Meta-analysis

Posted Date: March 4th, 2021

DOl: https://doi.org/10.21203/rs.3.rs-263098/v1

License: () (i) This work is licensed under a Creative Commons Attribution 4.0 International License. Read Full License 


\section{Abstract}

Background and Objectives: The adjuvant treatment of stem cell therapy for acute myocardial infarction (AMI) has been studied in multiple clinical trials, but many questions remain to be answered, such as the best seed cells, transplant dosage, and transplant timing. We conducted a meta-analysis of randomized controlled trials to explore the issues related to the treatment of AMI based on mesenchymal stem cells (MSCs) transplantation and to guide the design of subsequent clinical studies to achieve better clinical endpoints.

Methods: The Pubmed, Embase databases, and Cochrane Library were searched for clinical studies between January 1, 2000, and January 23, 2021. Studies that evaluated the effect of MSCs transplantation on AMI were identifified. According to the Cochrane systematic review method, the literature quality of the included studies was evaluated, and valid data were extracted. RevMan 5.3 and Stata 15.1 software were used for Meta-analysis.

Results: After a literature search and detailed evaluation, 9 randomized controlled trials with a total of 460 individuals were included in the quantitative analysis. Pooled analyses indicated that MSCs transplantation was associated with a greater improvement of left-ventricular ejection fraction (LVEF) (mean difference [MD], 3.08\%; 95\% confidence interval [CI], 1.81 to $\left.4.35 ; P<0.00001 ; I^{2}=89 \%\right)$ than controls. A subgroup analysis was conducted to explore the results according to differences in follow-up time, transplantation dose and time of MSCs injected. The improvement effect of LVEF was maintained for up to 24 months after MSCs treatment. For transplantation dose, the LVEF of patients who accepted a MSC dose of $10^{7}-10^{8}$ cells exhibited an LVEF improvement of $2.62 \%\left(95 \% \mathrm{Cl} 1.54\right.$ to $\left.3.70 ; P<0.00001 ; I^{2}=0 \%\right)$, but this improvement was insignificant in the subgroup that accepted a MSC dose of $<10^{7}$ cells $(1.65 \%$ in LVEF, $95 \% \mathrm{Cl}, 0.03$ to 3.27; $\left.P=0.05 ; I^{2}=75 \%\right)$ or $>10^{8}$ cells $\left(4.65 \%\right.$ in LVEF, $95 \% \mathrm{Cl},-4.55$ to $\left.13.48 ; P=0.32 ; I^{2}=95 \%\right)$, compared with the control. The LVEF of patients accepting a MSCs infusion within 2 to 14 days after Percutaneous coronary intervention (PCI) was significantly increased by $3.18 \%\left(95 \% \mathrm{Cl}, 2.89\right.$ to $\left.3.47 ; P<0.00001 ; \mathrm{I}^{2}=0\right)$. MSCs therapy was not associated with an increased risk of major adverse events.

Conclusion: Results from our systematic review suggest that MSCs transplantation can improve the heart function of patients with $\mathrm{AMI}$, and the effect was maintained for up to 24 months. MSC dose of $10^{7}-10^{8}$ cells was more likely to achieve better clinical endpoints than $<10^{7}$ or $>10^{8}$ cells. The optimal time window for cell transplantation may be within 2-14 days after PCl.

\section{Background}

In the past decade, drugs and device-based treatment strategies have made significant progress, which has improved the prognosis of acute myocardial infarction (AMI), but it is still the main cause of morbidity and mortality worldwide. The number of cardiovascular deaths is expected to increase to more than 23 million by 2030, according to a report from the American Heart Association[1]. The main reason is that although the existing medical and surgical treatment methods can improve coronary blood supply and save ischemic myocardium, there are no good treatments for necrotic myocardium or non-functional myocardium. In 
addition to heart transplantation, it cannot solve the loss of cardiomyocytes from myocardial necrosis[2]. However, the limited number of donors also limits the implementation of heart transplantation[3]. In this regard, stem cell-based cell therapy has shown the potential to repair damaged cardiomyocytes[4].

Stem cells are a type of undifferentiated cells or primitive cells, which are early undifferentiated cells that have the ability to self-replicate and can differentiate into at least one type of functional cell[5]. Under certain conditions, stem cells can differentiate into functional cells in the body to form any type of tissues and organs, that is, "plasticity". Stem cells can be divided into embryonic stem cells (ESCs) and adult stem cells, according to the order of appearance during the ontogeny. When the fertilized egg divides and develops into a blastocyst, the cells in the inner cell mass are ESCs. Adult stem cells refer to those stem cells with tissue or organ specificity, with strong plasticity and a wide range of tissue types[6]. Stem cells related to cardiomyocyte therapy, such as bone marrow mononuclear stem cells, CD133, CD34, bone marrow mesenchymal stem cells, adipose tissue regeneration cells, and umbilical cord blood mesenchymal stem cells, have been performed in AMI patients[7-10].

Although there have been more than ten years of clinical studies on stem cell transplantation for the treatment of acute myocardial infarction, these studies have mainly focused on bone marrow mononuclear cells. Previously highly cited clinical system reviews indicate that there was insufficient evidence that stem cell therapy had a beneficial effect in patients with AMI[11]. It is worth noting that the results of these reviews were mainly driven by clinical trials using autologous bone marrow monocytes. Preclinical studies have shown that MSCs may be more effective than bone marrow mononuclear cell types in the treatment of ischemic heart disease models[12]. A meta-analysis based on 52 animal studies also suggests that bone marrow mononuclear cells are less effective than mesenchymal stem cells[13]. At present, the research focus of cardiac cell therapy has turned to mesenchymal stem cells. However, the clinical results of each individual study are still controversial. To some extent, these contradictions can be explained by differences in the number of people studied, the route of cell administration, the time of cell infusion, and the dose of cell injection. Therefore, we use LVEF to evaluate the improvement of cardiac function, and conduct subgroup analysis to explore the optimal cell infusion time and cell injection dose for this cell type. The current Meta-analysis was carried out to explore the related problems of the treatment of AMI based on MSCs cell transplantation and to guide the design of subsequent clinical studies to achieve better clinical outcomes, according to the published collective data of RCT.

\section{Materials And Methods}

\subsection{Search strategy}

This comprehensive meta-analysis was conducted according to the Preferred Reporting Items for Systematic Reviews and Meta-Analyses (PRISMA) guidelines[14]. To identify all published clinical studies that evaluated the effects of MSCs therapy on acute myocardial infarction, we performed a comprehensive online search of the published literature using the Pubmed, Embase databases, and Cochrane Library (January 1,2001 , to January 23, 2021). In addition, we have checked the related randomized controlled trial (RCT) published and ongoing on the www.clinicaltrials.gov. The search strategy used medical subject 
heading terms and relevant keywords, including Mesenchymal Stem Cells, Myocardial Infarction, Mesenchymal Stromal Cell, Bone Marrow Stromal Stem Cells, Adipose Derived Mesenchymal Stromal Cells, Wharton's Jelly Cells, etc. The search was limited to RCTs and the transplantation of MSCs only in the experimental group.

\subsection{Study selection}

Inclusion criteria: 1) RCT. 2) There was a detailed research protocol with rigorous inclusion and exclusion criteria. 3) The subjects included in the study were patients with a clear diagnosis of acute myocardial infarction. 4) Participants were randomly allocated to MSCs or control groups (all participants were treated with optimum medical treatment and primary PCl after $\mathrm{AMI}$ ). 5)The types of transplanted stem cells were limited to MSCs, but the origin of MSCs were not limited (bone marrow, umbilical cords, or adipose tissue). 6)Studies did not restrict the administration route, transplantation time and cell dosage. Exclusion criteria were not clinical trials; injection of cells other than MSCs; studies other than RCTs, case report, review, or conference summary; data conflicts and studies not written in English.

\subsection{Data extraction}

Data extraction and analysis were performed independently by two different researchers, and standard information was entered into a customized data extraction form. The following data were extracted: first author, year of publication, country, sample size, study design, route of administration, MSC cell type, route of delivery, cell origin, injection dose, primary intervention, time from intervention to cell infusion, follow-up duration (months), and change in LVEF, left ventricular end-systolic volume (LVESV), and left ventricular enddiastolic volume (LVEDV). All data were extracted in accordance with criteria based on a new edition of the Cochrane Handbook for Systematic Reviews of Interventions[15].

\subsection{Quality assessment}

The potential risk of bias of randomized controlled trials was assessed using criteria based on the Cochrane Collaboration's tool for assessing risk of bias[16]. Each study was examined for random sequence

generation, allocation concealment, blinding of participants and personnel, blinding of outcome assessment, incomplete outcome data, selective outcome reporting, and other sources of bias, using a risk scale to evaluate the quality as high, low, or unclear risk as implemented in RevMan 5.3 software. The quality assessments were independently conducted by two authors. If any disagreements were encountered, two authors shall resolve them by discussion.

\subsection{Statistical analyses}

Outcome data were analyzed using Review Manager 5.3 and Stata15.1 software. Data were calculated using the inverse variance formula ${ }^{[17]}$. For continuous variables, MSCs treatment effects were calculated analyzed using weighted mean differences (MDs) with 95\% confidence intervals (Cl). For dichotomous data, MSCs treatment safety were analyzed using relative risk (RR) with $95 \% \mathrm{Cl}$. Using RevMan5.3 software to draw forest plot for the included studies, the heterogeneity test, the test level is $\mathrm{a}=0.1$. The Q-statistic were 
used to examine heterogeneity, and the extent of the observed heterogeneity was assessed using the $\mathrm{I}^{2}$ statistic (ranging from 0 to $100 \%$ ). Heterogeneity was defined as low $\left(I^{2}<25 \%\right.$ ), intermediate $\left(l^{2} 25\right.$ to $50 \%$ ), or high $\left(I^{2}>50 \%\right)$. If $I^{2}<50 \%$ and $p<0.05$, a fixed effects model was used for data calculation. Otherwise, a random effects model was applied and It was necessary to further explore the source of heterogeneity, and conduct a subgroup analysis of the factors that may lead to heterogeneity. If there is unexplainable clinical heterogeneity, then abandon meta-analysis and perform descriptive integration. Sensitivity analysis using the one study remove method and subgroup analysis was performed to test the stability of our metaanalysis further. We assessed publication bias by viewing funnel plots. The asymmetry of funnel plots indicates that there is no publication bias in the Meta-analysis. The Begg adjusted rank correlation test and the Egger regression asymmetry test of each endpoint were performed with Stata15.1 to further assessed asymmetry.

\section{Results}

\subsection{Search results}

The initial search identified 481 articles (Pubmed=91; Embase databases=263; The Cochrane Library=127), of which 464 references were excluded because of duplication, reviews, reviews, animal experiments, and inconsistent research content. Then, 17 articles were read in full, and 10 articles were finally included, of which 1 article [18] was excluded because of statistical contradictions in the LVEF baseline data. Finally, 9 articles with 460 patients were included. A flow diagram depicting studies selection process is demonstrated in Fig. 1.

\subsection{Characteristics and quality of included studies}

In total, 460 patients with AMI (MSCs group 240, control group 220) from 9 RCT were available for the final meta-analysis. Publication years were from 2004 to 2021. Follow-up duration was from 3 to 24 months. MSC was infused into intracoronary (7 studies) [9] [10] [19] [20] [21] [22] [23] and intravascular (2 studies) [24] [25] routes. Total injected cell doses ranged from $<10^{7}$ to $>10^{8}$, and infusion time after PCl was between less than 2 days and 2 weeks later. The origin of MSCs were bone marrow (7 studies) [19] [24] [20] [21] [25] [22] [23], adipose tissue (1 study) [9], and umbilical cords (1 study) [10]. The main characteristics of each individual study are summarized in Table 1 and Table 2. The methodological quality of the enrolled studies was assessed using RevMan 5.3 as shown in Fig. 2 and Fig. 3.

TABLE1. Basic characteristics of involved studies 


\begin{tabular}{|c|c|c|c|c|c|c|}
\hline $\begin{array}{l}\text { Author, } \\
\text { year }\end{array}$ & Country & $\begin{array}{l}\text { Sample } \\
\text { size n(T/C) }\end{array}$ & Age (T/C years) & $\begin{array}{l}\text { Study } \\
\text { design }\end{array}$ & Setting & Population \\
\hline $\begin{array}{l}\text { Chen et } \\
\text { al., } \\
2004^{[19]}\end{array}$ & China & $69(34 / 35)$ & $58 \pm 7 / 57 \pm 5$ & RCT & $\begin{array}{l}\text { Single- } \\
\text { center }\end{array}$ & AMI \\
\hline $\begin{array}{l}\text { Hare et al., } \\
2009^{[24]}\end{array}$ & USA & $60(39 / 21)$ & $59.0 \pm 12.3 / 55.1 \pm 10.2$ & RCT & $\begin{array}{l}\text { multi- } \\
\text { center } \\
(10)\end{array}$ & AMI \\
\hline $\begin{array}{l}\text { Houtgraaf } \\
\text { et al., } \\
2012^{[9]}\end{array}$ & Netherlands & $14(10 / 4)$ & $61 \pm 2.1 / 55 \pm 7.5$ & RCT & $\begin{array}{l}\text { Single- } \\
\text { center }\end{array}$ & AMI \\
\hline $\begin{array}{l}\text { Gao et al., } \\
2013^{[20]}\end{array}$ & China & $43(21 / 22)$ & $55.0 \pm 1.6 / 58.6 \pm 2.5$ & RCT & $\begin{array}{l}\text { multi- } \\
\text { center } \\
\text { (4) }\end{array}$ & AMI \\
\hline $\begin{array}{l}\text { Lee et al., } \\
2014^{[21]}\end{array}$ & $\begin{array}{l}\text { South } \\
\text { Korea }\end{array}$ & $69(33 / 36)$ & $53.9 \pm 10.5 / 54.2 \pm 7.7$ & RCT & $\begin{array}{l}\text { multi- } \\
\text { center } \\
\text { (3) }\end{array}$ & AMI \\
\hline $\begin{array}{l}\text { Gao et al., } \\
2015^{[10]}\end{array}$ & China & $116(58 / 58)$ & $56.7 \pm 1.7 / 57.3 \pm 1.3$ & RCT & $\begin{array}{l}\text { multi- } \\
\text { center } \\
(11)\end{array}$ & AMI \\
\hline $\begin{array}{l}\text { Chullikana } \\
\text { et } \\
\text { al.,2015 [25] }\end{array}$ & India & $20(10 / 10)$ & $47.31 \pm 12.10 / 47.79 \pm 6.48$ & RCT & $\begin{array}{l}\text { multi- } \\
\text { center } \\
\text { (4) }\end{array}$ & AMI \\
\hline $\begin{array}{l}\text { kim SH et } \\
\text { al., } \\
2018^{[22]}\end{array}$ & $\begin{array}{l}\text { South } \\
\text { Korea }\end{array}$ & $26(14 / 12)$ & $57.8 \pm 8.9 / 55.3 \pm 8.6$ & RCT & $\begin{array}{l}\text { Single- } \\
\text { center }\end{array}$ & AMI \\
\hline $\begin{array}{l}\text { Zhang et } \\
\text { al., } \\
2021^{[23]}\end{array}$ & China & $43(21 / 22)$ & $59.3 \pm 9 / 58.6 \pm 11$ & RCT & $\begin{array}{l}\text { multi- } \\
\text { center } \\
\text { (6) }\end{array}$ & AMI \\
\hline
\end{tabular}

Note: RCT randomized controlled trail; $A M I$ acute myocardial infarction.

TABLE 2. Procedural characteristics of involved studies 


\begin{tabular}{|c|c|c|c|c|c|c|}
\hline Author, year & Cell type & Cell dose & $\begin{array}{l}\text { Time of cell } \\
\text { therapy } \\
\text { (post-PCl) }\end{array}$ & $\begin{array}{l}\text { Route of } \\
\text { delivery }\end{array}$ & $\begin{array}{l}\text { Follow-up } \\
\text { (months) }\end{array}$ & Endpoint \\
\hline \multirow{2}{*}{$\begin{array}{l}\text { Chen et al., } \\
2004^{[19]}\end{array}$} & Autologous & \multirow[t]{2}{*}{$8-10 \times 10^{\wedge} 9$} & \multirow{2}{*}{$\begin{array}{l}18.4 \pm 0.5 \\
\text { days }\end{array}$} & \multirow[t]{2}{*}{ IC } & \multirow[t]{2}{*}{3,6} & \multirow[t]{2}{*}{ ૫ } \\
\hline & BM-MSCs & & & & & \\
\hline \multirow[t]{2}{*}{$\begin{array}{l}\text { Hare et al., } \\
2009^{[24]}\end{array}$} & $\begin{array}{l}\text { Unmatched } \\
\text { allogeneic }\end{array}$ & \multirow[t]{2}{*}{$0.5,1.6,5 \times 10^{\wedge} 6$} & \multirow[t]{2}{*}{$\begin{array}{l}\text { Randomized } \\
1-10 \text { days }\end{array}$} & \multirow[t]{2}{*}{ IV } & \multirow[t]{2}{*}{$3,6,12$} & \multirow[t]{2}{*}{ 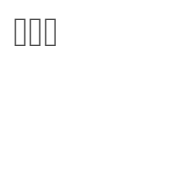 } \\
\hline & BM-MSCs & & & & & \\
\hline \multirow{2}{*}{$\begin{array}{l}\text { Houtgraaf et } \\
\text { al., 2012 }\end{array}$} & Autologous & \multirow[t]{2}{*}{$1.74 \pm 0.41 \times 10^{\wedge} 7$} & \multirow[t]{2}{*}{24 hours } & \multirow[t]{2}{*}{ IC } & \multirow[t]{2}{*}{6} & \multirow[t]{2}{*}{ प } \\
\hline & ADRCs & & & & & \\
\hline \multirow{2}{*}{$\begin{array}{l}\text { Gao et al., } \\
2013^{[20]}\end{array}$} & Autologous & \multirow[t]{2}{*}{$3.08 \pm 0.52 \times 10^{\wedge} 6$} & \multirow[t]{2}{*}{$17 \pm 1$ days } & \multirow[t]{2}{*}{ IC } & \multirow[t]{2}{*}{$6,12,24$} & \multirow[t]{2}{*}{ प्रा } \\
\hline & BM-MSCs & & & & & \\
\hline \multirow{2}{*}{$\begin{array}{l}\text { Lee et al., } \\
2014^{[21]}\end{array}$} & Autologous & \multirow[t]{2}{*}{$7.2 \pm 0.90 \times 10^{\wedge} 7$} & \multirow[t]{2}{*}{$25 \pm 2.4$ days } & \multirow[t]{2}{*}{ IC } & \multirow[t]{2}{*}{6} & \multirow[t]{2}{*}{ प्रा } \\
\hline & BM-MSCs & & & & & \\
\hline \multirow[t]{2}{*}{$\begin{array}{l}\text { Gao et al., } \\
2015^{[10]}\end{array}$} & $\begin{array}{l}\text { Unmatched } \\
\text { allogeneic }\end{array}$ & \multirow[t]{2}{*}{$2 \times 10^{\wedge} 8$} & \multirow[t]{2}{*}{ 5-7 days } & \multirow[t]{2}{*}{ IC } & \multirow[t]{2}{*}{$4,12,18$} & \multirow[t]{2}{*}{ 吅 } \\
\hline & WJ-MSCs & & & & & \\
\hline $\begin{array}{l}\text { Chullikana et } \\
\text { al.,2015 }\end{array}$ & $\begin{array}{l}\text { Unmatched } \\
\text { allogeneic }\end{array}$ & $2 \times 10^{\wedge} 6 / \mathrm{kg}$ & 2 days & IV & 6,24 & प \\
\hline & BM-MSCs & & & & & \\
\hline kim SH et al., & Autologous & $7.2 \pm 0.90 \times 10^{\wedge} 7$ & $30 \pm 1.3$ days & IC & 4,12 & 》 驲 \\
\hline $2018^{[2-1}$ & BM-MSCs & & & & & \\
\hline Zhang et al., & Autologous & $3.31 \pm 1.7 \times 10^{\wedge} 6$ & $14.07 \pm 9.53$ & IC & 6,12 & 》 姆 \\
\hline$\angle 0 \angle 1+2$ & BM-MSCs & & & & & \\
\hline
\end{tabular}

Note: BM-MSCs bone marrow mesenchymal stem cells; ADRCs Adipose Tissue-Derived Regenerative Cells;

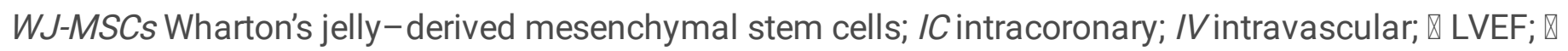

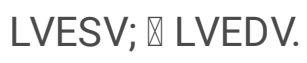

\subsection{Overall effects of MSCs therapy on LVFE}

The 9 studies included in present meta-analysis were tested for heterogeneity, $I^{2}=89 \%>50 \%$, and the Q-test $P<0.1$, suggesting that there was high degree of heterogeneity between these studies. Therefore, we can choose a random effects model to summarize the data, or conduct a sensitivity analysis to confirm the statistical power of the study and seek out the heterogeneity sources (Fig. 4). Base on the random effects model, the results of our analysis indicated that overall LVEF is increased by $3.08 \%(95 \% \mathrm{Cl}, 1.81$ to $4.35 ; P$ 
$<0.00001$ ) compared to the control group (Fig. 5a). The initial result did not change when we removed the studies one by one. However, we observed that, when ignoring the studies by Chen et al., 2004[19] and Gao et al., 2013[20], the $\mathrm{I}^{2}$ value changed from $89 \%$ to $0 \%$ (Fig. 5b). Therefore, we hypothesize that the two studies may be sources of heterogeneity. After ignoring the two studies, injection of MSCs improved LVEF by $3.13\left(95 \% \mathrm{Cl}, 2.85\right.$ to $\left.3.41 ; P<0.00001 ;\left.\right|^{2}=0 \%\right)$. We highly suspect that the source of the heterogeneity was the follow-up time, the dose and timing of stem cell transplantation, and subsequent subgroup analysis was conducted. The funnel plots was used to investigate whether there was publication bias in this study (Fig. 6). The basic symmetry of the funnel plots means that there was no publication bias. Using the Stata 15.1 to perform the begg test, $P=0.917>0.05$, and the egger test, $P=0.837>0.05$, which means that there was no publication bias in the 9 articles included in this study.

\subsection{Effects of MSCs therapy on LVFE over time}

Pooled statistics revealed that MSCs group did not improve in less than 3 months of follow-up compared with control group (MD, 7.38\%; $95 \% \mathrm{Cl},-2.67$ to $17.43 ; P=0.14 ; \mathrm{I}^{2}=90 \%$ ). The effect of MSCs in improving LVEF gradually appeared after 4 months of follow-up. However, this beneficial effect seems to diminish over time. LVEF increased by $3.21 \%\left(95 \% \mathrm{Cl}, 2.91\right.$ to $\left.3.50 ; P<0.00001 ; \mathrm{I}^{2}=0 \%\right), 3.56 \%(95 \% \mathrm{Cl}, 1.62$ to 5.51 ; $P=0.0003$ to $\left.\mathrm{I}^{2}=87 \%\right), 2.48 \%\left(95 \% \mathrm{Cl}, 1.16\right.$ to $\left.3.80 ; P=0.0002 ; \mathrm{I}^{2}=93 \%\right)$ and $0.81 \%(95 \% \mathrm{Cl}, 0.37$ to 1.24 ; $P=0.0003 ; I^{2}=0 \%$ ) in $4,6,12$ and 24 months respectively (Fig. 7a). We performed a sensitivity analysis for the subgroup at 6-month and 12-month follow-up. When omitting the studies one by one, we did not find the opposite result. Interestingly, when we ignore the results from Chen et al., 2004 [19] and Gao et al., 2013 [20], $\mathrm{I}^{2}$ change from $87 \%$ to $0 \%$ in the 6-month group; delete the result from Chullikana et al., $2015, \mathrm{I}^{2}$ decreased from $93 \%$ to $0 \%$ in the 12 -month. In the result of 2015 , the 12 value changed from $93 \%$ to $0 \%$ (Fig. $7 \mathrm{~b}$ ). However, in cardiac parameters of LVESV and LVEDV, we have not found that MSCs treatment has a significant improvement effect, which may be related to the existence of heterogeneity (Fig. 8).

\subsection{The dose of MSCs therapy}

According to the combined data of dose subgroup, patients who injected more than 108 cells did not benefit more than patients with low cell doses. More specifically, for patients who received cell doses between $10^{7}$ and $10^{8}$, LVEF was significantly improved by $2.62 \%\left(95 \% \mathrm{Cl}, 1.54\right.$ to $\left.3.70 ; P<0.00001 ; I^{2}=0 \%\right)$. However, this result was not observed in the high cell dose group $\left(>10^{8}\right.$ cells) (Fig. 9).

\subsection{The timing of MSCs therapy}

Compared with the control group, MSCs transplantation within 2 days after AMI did not significantly improve LVEF. Cell therapy within 2 to 14 days after AMI increased LVEF by $3.18 \%(95 \% \mathrm{Cl}, 2.89$ to 3.47 ; $\left.P<0.00001 ; I^{2}=0 \%\right)$. For cell transplantation $>14$ days after $P C l, L V E F$ also increased significantly by $3.37 \%$ $\left(95 \% \mathrm{Cl}, 1.04\right.$ to $\left.5.69 ; P=0.004 ; I^{2}=89 \%\right)$, but there was a high degree of heterogeneity (Fig. 10a). Further sensitivity analysis, we found that when Chen et al., 2004 [19] and Gao et al., 2013 [20] were ignored, the ${ }^{2}$ value dropped from $89 \%$ to $23 \%$. The improvement of LVEF in the transplantation group greater than 14 days seems to be lower than that in the transplantation group within 2 to 14 days (Fig. 10b). 


\subsection{The safety of MSCs therapy}

7 studies reported all-cause mortality (OR $1.86 ; 95 \% \mathrm{Cl}, 0.39$ to $8.90 ; \mathrm{I}^{2}=0 ; P=0.44$ (Fig. 11). The data shows that compared with the control group, MSC treatment was safe for patients with AMI.

\section{Discussion}

Many clinical studies have suggested that stem cell therapy had a beneficial effect on heart repair. However, the results of various studies were inconsistent, and many questions remain to be answered, such as the optimal seed cell, cell dose, and transplant timing. Myocardial repair requires mature cardiomyocytes and coronary blood vessels. Myocardial regeneration and vascular regeneration must be produced at the same time. The transplanted seed cells must have the ability to differentiate into mature cardiomyocytes and regenerate into coronary artery resistance vessels at the same time to achieve the purpose of active transplantation. Therefore, seeking a pluripotent stem cell that can better meet the above conditions has always been a key issue for stem cell treatment of cardiovascular diseases. Among the many transplanted seed cells, bone marrow mononuclear cells are currently the most frequently used cell type in clinical research. That may be due to its simple separation and preparation, and does not increase the incidence of clinical adverse reactions such as infection, restenosis in the stent, arrhythmia, and microthrombosis. However, its cellular components are complex, the content of stem cells is very low, the probability of differentiation into cardiomyocytes and vascular endothelial cells is very low (about 1 in 10,000). Therefore, the role of bone marrow monocytes in repairing infarcted cardiomyocytes is very limited. MSC is currently one of the most promising types of stem cells [26]. MSCs share the common characteristics of stem cells: continuous self-renewal, multi-directional differentiation ability, strong proliferation ability, multi-directional differentiation potential and immune regulation. MSCs do not express obvious histocompatibility complexes and immunostimulatory molecules, so they cannot be detected by immune monitoring and will not cause transplant rejection after transplantation [27].

In this systematic review and Meta-analysis of 9 RCTs, a total of 460 patients with AMI were included. We found that MSCs therapy was related to the improvement of ejection fraction in patients with acute myocardial infarction, and cell therapy was proven to be safe. Interestingly, in a short period of time (3 months) after MSCs treatment, its effect on LVEF after AMI was not obvious, but as time goes by, its effect gradually appears and was significant, which could last at least 2 years. We speculate that this phenomenon may be related to local inflammation or stem cell differentiation time. Further research is needed to clarify this point.

It is difficult to determine the optimal cell dose. It is believed that the dose is positively associated to the improvement of heart function, and transplantation of high doses of cells is more effective than low doses to treat damaged myocardium. The results of several clinical studies have shown that high-dose MSCs $\left(10^{8}\right.$ cells) were more effective in improving $\operatorname{LVEF}[28,29]$. In our previous clinical studies, the use of low cell doses ( $<10^{7}$ cells) did not find significant improvement in cardiac function [23]. Our meta-analysis results indicate that the optimal therapeutic dose of MSCs cell therapy may be $10^{7} \sim 10^{8}$ cells. On the one hand, to overcome the initial cell death and extravasation caused by hypoxia and intracoronary injection and migrate 
to the infarct area, resulting in a low successful implantation rate of cells, a higher initial dose is required. On the other hand, a higher number (more than $10^{8}$ cells) may be associated with a risk of microvascular embolism and might impair blood flow when injected into the coronary artery, thereby reducing the efficacy.

The timing of cell transplantation is a complex issue, which involves involves the balance between multiple factors, such as the relationship between the inflammatory factor release curve after AMI and the survival rate of transplanted cells, the release cycle of factors that promote stem cell homing, and the natural progression of cardiomyocytes after AMI. In this meta-analysis, we found that MSCs therapy within 2-14 days after PCl was more effective than MSCs transplantation within 2 days or 14 days after $\mathrm{PCl}$. The results of present study also explain the negative results of our previous clinical trials [23]. The reason for the negative results of transplantation within 2 days after myocardial infarction may be due to the bad local microenvironment such as inflammation, which caused the death of a large number of transplanted cells, thereby affecting the transplantation effect. Xu JY et al. [30] also found that the improvement of the cardiac microenvironment is essential for cell-based therapy. However, when the cell transplantation time is selected 14 days afterAMI, the local damage is irreversible, ventricular remodeling, and fibrosis has formed, which may further affect the effect.

MSCs from different sources have a considerable degree of similarity. Mesenchymal stem cells (MSC) derived from bone marrow and adipose tissue have the same efficiency in evaluating parameters [31]. Compared with bone marrow mesenchymal stem cells, umbilical cord mesenchymal stem cells secrete higher levels of immune signal molecules and neurotrophic factors, which can better support neurogenic related processes and have higher proliferation ability [32], while bone marrow Mesenchymal stem cells can enhance angiogenesis [33]. At present, the mechanism of intramyocardial transplantation of mesenchymal stem cells to improve ischemic heart function is not yet clear, but it is believed to be related to the following mechanisms: 1) differentiation of transplanted cells. MSCs differentiate into cardiomyocyte-like cells, which are used as raw materials to repair myocardium and rebuild infarcted myocardium. MSCs differentiate into endothelial cells and smooth muscle cells to form new blood vessels to supply ischemic myocardium and rescue myocardial cells near apoptosis [34]. 2) stimulate the proliferation, differentiation and regeneration of endogenous cardiac stem cells (CSC) [35]. 3) paracrine effect. MSCs can mediate heart repair through autocrine, paracrine and endocrine axes [36]. MSCs produce a large number of vasoactive peptides through autocrine and paracrine functions, which directly enhance heart function and expand blood vessels. The microvesicles of MSCs secrete a variety of factors that promote their angiogenesis, and have the function of promoting the regeneration of the host myocardium and the formation of collateral circulation [37]. 4) Interaction between cells. MSC improves the survival rate and angiogenesis of CSC through exosomes [38]. In addition, MSCs can also improve energetics by transferring mitochondria [39].

\section{Limitations}

Our research had several limitations. First of all, there were fewer studies on the treatment of AMI with MSCs, and more RCTs were needed. Secondly, in the aggregated data, the heterogeneity was very obvious, which may be due to the inconsistency of the follow-up duration, the cell dose and the timing of stem cell transplantation. Finally, Since there were fewer trials included in each subgroup analysis, we cannot analyze 
the efficacy of cell injection timing and dose combination. Therefore, more basic and clinical studies are needed to examine the effects of MSCs transplantation in the treatment of AMI, possible mechanisms, and standardize the methods of MSCs transplantation.

Stem cell treatment of AMI is a very promising treatment strategy. Clinical research should be established on a sufficient theoretical basis. The basic research of stem cell transplantation should be actively strengthened, such as the molecular level, cell level, and overall experimental animal level of stem cell differentiation regulation, signal transduction, homing, and stem cell mechanism. Similar to other new technologies, early failures are not uncommon and they may be followed by impressive success. In summary, while stem cell therapy might not help the cardiovascular patient in the near term, it is destined to do so over the next several decades.

\section{Conclusion}

Results from our systematic review suggest that MSCs transplantation can improve the heart function of patients with $\mathrm{AMI}$, and the effect was maintained for up to 24 months. MSC dose of $10^{7}-10^{8}$ cells was more likely to achieve better clinical endpoints than $<10^{7}$ or $>10^{8}$ cells. The optimal time window for cell transplantation may be within 2-14 days after PCl.

\section{Abbreviations}

MSCs

Mesenchymal stem cells

LVEF

Left-ventricular ejection fraction

LVESV

Left ventricular end-systolic volume

LVEDV

left ventricular end-diastolic volume.

MD

mean difference

$\mathrm{Cl}$

confidence interval

$\mathrm{PCl}$

Percutaneous coronary intervention

AMI

Acute myocardial infarction

ESCs

Embryonic stem cells

RCT

Randomized controlled trail

CSC 
endogenous cardiac stem cells

\section{Declarations}

\section{Acknowledgement}

Not applicable

\section{Funding}

This work was supported by the Scientific Research Projects of Sichuan Medical Planning Commission: Heart transplantation effect of stem cells-Study on Paracrine Mechanism (100306).

\section{Availability of data and materials}

Available data in this study exist in the above randomized controlled trails.

\section{Authors' contributions}

Jiang Yu contributed to the conception of this study. Jiang Yu and Run-feng Zhang contributed significantly to the analysis and manuscript preparation. Jiang Yu, Yi-li Mao, and Heng Zhang performed the data analysis and wrote the manuscript. Run-feng Zhang helped perform the analysis with constructive discussions. All authors read and approved the final manuscript.

\section{Competing interests}

The authors declare that they have no competing interests.

\section{Consent for publication}

Not applicable.

\section{Ethics approval and consent to participate}

Not applicable.

\section{References}

1. Benjamin EJ, Blaha MJ, Chiuve SE,et al. Heart Disease and Stroke Statistics-2017 Update: A Report From the American Heart Association[J]. Circulation. 2017;135(10):e146-603.

2. Reed GW, Rossi JE, Cannon CP. Acute myocardial infarction[J]. Lancet. 2017;389(10065):197-210.

3. Hu XJ, Dong NG, Liu JP,et al. Status on Heart Transplantation in China[J]. Chin Med J (Engl). 2015;128(23):3238-42.

4. Eschenhagen T, Bolli R, Braun T,et al. Cardiomyocyte Regeneration: A Consensus Statement[J]. Circulation. 2017;136(7):680-6. 
5. Shi $\mathrm{Y}$, Inoue $\mathrm{H}, \mathrm{Wu} \mathrm{JC}$,et al. Induced pluripotent stem cell technology: a decade of progress[J]. Nat Rev Drug Discov. 2017;16(2):115-30.

6. Terashvili M. Bosnjak ZJ Stem Cell Therapies in Cardiovascular Disease[J]. J Cardiothorac Vasc Anesth. 2019;33(1):209-22.

7. Colombo A, Castellani M, Piccaluga E,et al. Myocardial blood flow and infarct size after CD133 + cell injection in large myocardial infarction with good recanalization and poor reperfusion: results from a randomized controlled trial[J]. J Cardiovasc Med (Hagerstown). 2011;12(4):239-48.

8. Quyyumi AA, Vasquez A, Kereiakes DJ,et al. PreSERVE-AMI: A Randomized, Double-Blind, PlaceboControlled Clinical Trial of Intracoronary Administration of Autologous CD34 + Cells in Patients With Left Ventricular Dysfunction Post STEMI[J]. Circ Res. 2017;120(2):324-31.

9. Houtgraaf JH, den Dekker WK, van Dalen BM,et al. First experience in humans using adipose tissuederived regenerative cells in the treatment of patients with ST-segment elevation myocardial infarction[J]. J Am Coll Cardiol. 2012;59(5):539-40.

10. Gao LR, Chen Y, Zhang NK,et al. Intracoronary infusion of Wharton's jelly-derived mesenchymal stem cells in acute myocardial infarction: Double-blind, randomized controlled trial[J]. BMC Medicine, 2015,13(1).

11. Fisher SA, Zhang H, Doree C,et al. Stem cell treatment for acute myocardial infarction[J]. Cochrane Database Syst Rev, 2015(9): Cd006536.

12. Tao B, Cui $M$, Wang $C$,et al. Percutaneous intramyocardial delivery of mesenchymal stem cells induces superior improvement in regional left ventricular function compared with bone marrow mononuclear cells in porcine myocardial infarcted heart[J]. Theranostics. 2015;5(2):196-205.

13. van der Spoel TI, Jansen of Lorkeers SJ, Agostoni P,et al. Human relevance of pre-clinical studies in stem cell therapy: systematic review and meta-analysis of large animal models of ischaemic heart disease[J]. Cardiovasc Res. 2011;91(4):649-58.

14. Liberati A, Altman DG, Tetzlaff J,et al. The PRISMA statement for reporting systematic reviews and meta-analyses of studies that evaluate health care interventions: explanation and elaboration[J]. Ann Intern Med. 2009;151(4):W65-94.

15. Cumpston $\mathrm{M}, \mathrm{Li}$ T, Page MJ,et al. Updated guidance for trusted systematic reviews: a new edition of the Cochrane Handbook for Systematic Reviews of Interventions[J]. Cochrane Database Syst Rev. 2019;10:Ed000142.

16. Higgins JP, Altman DG, Gøtzsche PC,et al. The Cochrane Collaboration's tool for assessing risk of bias in randomised trials[J]. Bmj. 2011;343:d5928.

17. Barde MP. Barde PJ What to use to express the variability of data: Standard deviation or standard error of mean?[J]. Perspect Clin Res. 2012;3(3):113-6.

18. Wang $X, X i$ WC, Wang F. The beneficial effects of intracoronary autologous bone marrow stem cell transfer as an adjunct to percutaneous coronary intervention in patients with acute myocardial infarction[J]. Biotechnol Lett. 2014;36(11):2163-8.

19. Chen SL, Fang WW, Ye F,et al. Effect on left ventricular function of intracoronary transplantation of autologous bone marrow mesenchymal stem cell in patients with acute myocardial infarction[J]. 
American journal of cardiology. 2004;94(1):92-5.

20. Gao LR, Pei XT, Ding QA,et al. A critical challenge: dosage-related efficacy and acute complication intracoronary injection of autologous bone marrow mesenchymal stem cells in acute myocardial infarction[J]. Int J Cardiol. 2013;168(4):3191-9.

21. Lee JW, Lee SH, Youn YJ,et al. A randomized, open-label, multicenter trial for the safety and efficacy of adult mesenchymal stem cells after acute myocardial infarction[J]. J Korean Med Sci. 2014;29(1):2331.

22. Kim SH, Cho JH, Lee YH,et al. Improvement in Left Ventricular Function with Intracoronary Mesenchymal Stem Cell Therapy in a Patient with Anterior Wall ST-Segment Elevation Myocardial Infarction[J]. Cardiovascular drugs and therapy /. sponsored by the International Society of Cardiovascular Pharmacotherapy. 2018;32(4):329-38.

23. Zhang R, Yu J, Zhang N,et al. Bone marrow mesenchymal stem cells transfer in patients with STsegment elevation myocardial infarction: single-blind, multicenter, randomized controlled trial[J]. Stem Cell Research and Therapy, 2021, 12(1).

24. Hare JM, Traverse JH, Henry TD,et al. A Randomized, Double-Blind, Placebo-Controlled, Dose-Escalation Study of Intravenous Adult Human Mesenchymal Stem Cells (Prochymal) After Acute Myocardial Infarction[J]. J Am Coll Cardiol. 2009;54(24):2277-86.

25. Chullikana A, Majumdar AS, Gottipamula S,et al. Randomized, double-blind, phase I/II study of intravenous allogeneic mesenchymal stromal cells in acute myocardial infarction[J]. Cytotherapy. 2015;17(3):250-61.

26. Shafei AE, Ali MA, Ghanem HG,et al. Mesenchymal stem cell therapy: A promising cell-based therapy for treatment of myocardial infarction[J]. J Gene Med, 2017, 19(12).

27. Bagno L, Hatzistergos KE, Balkan W,et al. Mesenchymal Stem Cell-Based Therapy for Cardiovascular Disease: Progress and Challenges[J]. Mol Ther. 2018;26(7):1610-23.

28. Perin EC, Borow KM, Silva GV,et al. A Phase II Dose-Escalation Study of Allogeneic Mesenchymal Precursor Cells in Patients With Ischemic or Nonischemic Heart Failure[J]. Circ Res. 2015;117(6):57684.

29. Florea V, Rieger AC, DiFede DL,et al. Dose Comparison Study of Allogeneic Mesenchymal Stem Cells in Patients With Ischemic Cardiomyopathy (The TRIDENT Study)[J]. Circ Res. 2017;121(11):1279-90.

30. Xu JY, Qian HY, Huang PS,et al. Transplantation efficacy of autologous bone marrow mesenchymal stem cells combined with atorvastatin for acute myocardial infarction (TEAM-AMI): rationale and design of a randomized, double-blind, placebo-controlled, multi-center, Phase II TEAM-AMI trial[J]. Regenerative medicine. 2019;14(12):1077-87.

31. Omar AM, Meleis AE, Arfa SA,et al. Comparative Study of the Therapeutic Potential of Mesenchymal Stem Cells Derived from Adipose Tissue and Bone Marrow on Acute Myocardial Infarction Model[J]. Oman Med J. 2019;34(6):534-43.

32. Hass R, Kasper C, Böhm S,et al. Different populations and sources of human mesenchymal stem cells (MSC): A comparison of adult and neonatal tissue-derived MSC[J]. Cell Commun Signal. 2011;9:12. 
33. Donders R, Bogie JFJ, Ravanidis S,et al. Human Wharton's Jelly-Derived Stem Cells Display a Distinct Immunomodulatory and Proregenerative Transcriptional Signature Compared to Bone Marrow-Derived Stem Cells[J]. Stem Cells Dev. 2018;27(2):65-84.

34. Toma C, Pittenger MF, Cahill KS,et al. Human mesenchymal stem cells differentiate to a cardiomyocyte phenotype in the adult murine heart[J]. Circulation. 2002;105(1):93-8.

35. Hatzistergos KE, Quevedo $\mathrm{H}$, Oskouei BN,et al. Bone marrow mesenchymal stem cells stimulate cardiac stem cell proliferation and differentiation[J]. Circ Res. 2010;107(7):913-22.

36. Sid-Otmane C, Perrault LP, Ly. HQ Mesenchymal stem cell mediates cardiac repair through autocrine, paracrine and endocrine axes[J]. J Transl Med. 2020;18(1):336.

37. Chen J, Liu Z, Hong MM,et al. Proangiogenic compositions of microvesicles derived from human umbilical cord mesenchymal stem cells[J]. PLoS One. 2014;9(12):e115316.

38. Zhang Z, Yang J, Yan W,et al. Pretreatment of Cardiac Stem Cells With Exosomes Derived From Mesenchymal Stem Cells Enhances Myocardial Repair[J]. J Am Heart Assoc, 2016, 5(1).

39. Jackson MV, Morrison TJ, Doherty DF,et al. Mitochondrial Transfer via Tunneling Nanotubes is an Important Mechanism by Which Mesenchymal Stem Cells Enhance Macrophage Phagocytosis in the In Vitro and In Vivo Models of ARDS[J]. Stem Cells. 2016;34(8):2210-23.

\section{Figures}




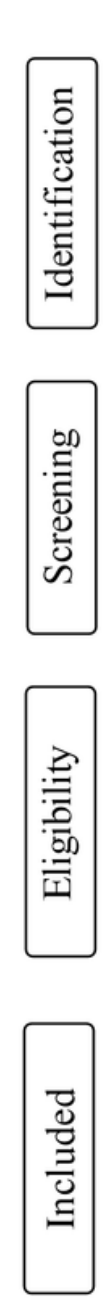


The Distribution of the Methodological Quality of Included Studies.

\begin{tabular}{|c|c|c|c|c|c|c|c|c|c|}
\hline 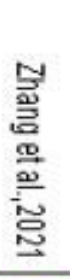 & 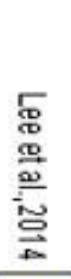 & 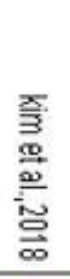 & 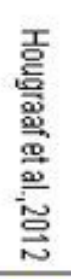 & 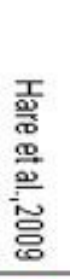 & 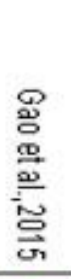 & 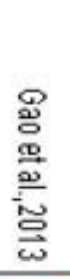 & 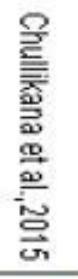 & 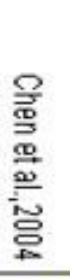 & \\
\hline+ & $\sim$ & + & $\sim$ & + & $\oplus$ & (1) & + & $\sim$ & Random sequence generation (selection bias) \\
\hline$\sim$ & $\sim$ & $\omega$ & $\sim$ & + & + & (1) & + & $\sim$ & Allocation concealment (selection bias) \\
\hline (1) & (1) & + & $\sim$ & + & + & (1) & + & $\sim$ & Blinding of participants and personnel (performance bias) \\
\hline+ & + & $\sim$ & $\sim$ & + & + & + & 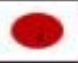 & $\oplus$ & Blinding of outcome assessment (detection bias) \\
\hline+ & + & + & + & + & + & 8 & + & + & Incomplete outcome data (attrition bias) \\
\hline+ & + & + & + & + & + & + & + & + & Selective reporting (reporting bias) \\
\hline+ & $\oplus$ & + & $\sim$ & (1) & + & + & P & $\sim$ & Other bias \\
\hline
\end{tabular}

\section{Figure 3}

Methodological Quality of Included Studies.

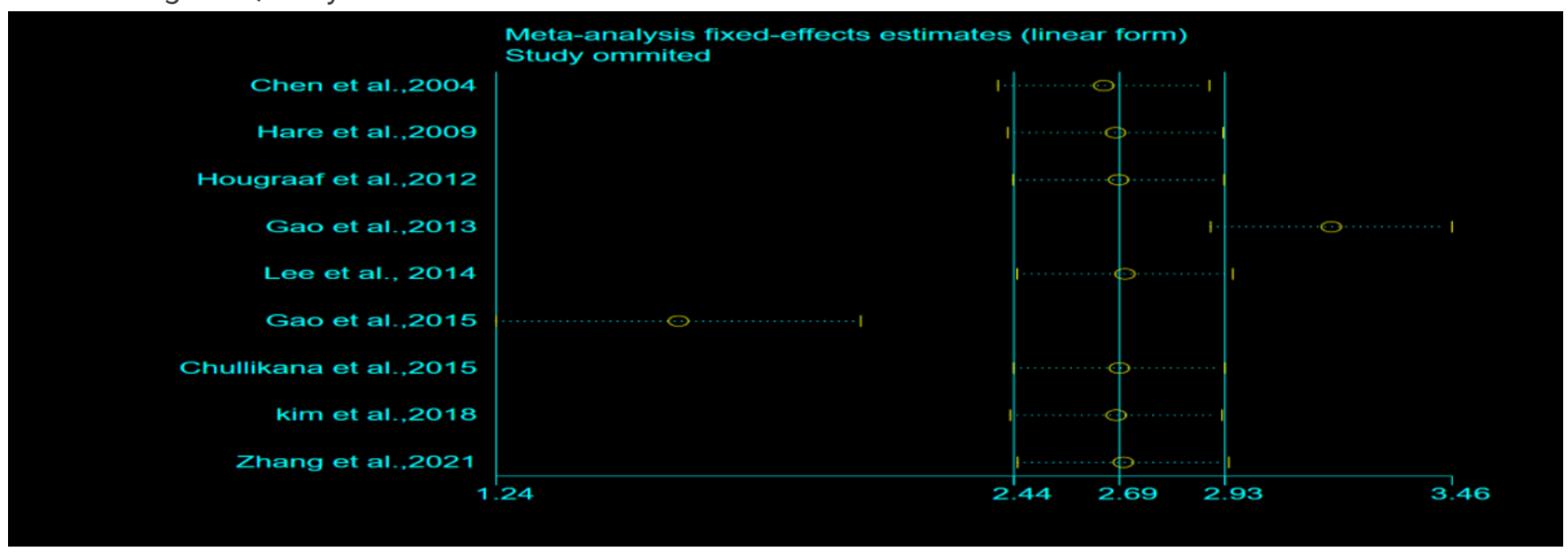

\section{Figure 4}

Sensitivity analysis for change in overall effects of MSCs therapy on LVEF. 
a

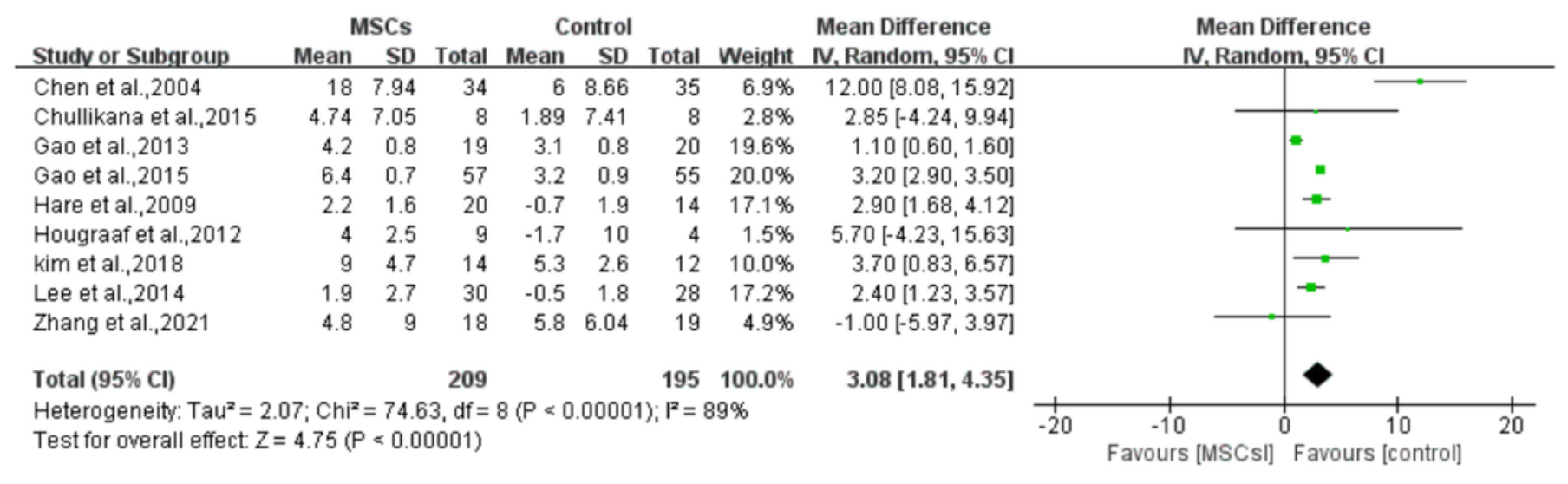

b

\begin{tabular}{|c|c|c|c|c|c|c|c|c|c|c|c|c|}
\hline \multirow[b]{2}{*}{ Study or Subgroup } & \multicolumn{2}{|c|}{ MSCs } & \multicolumn{3}{|c|}{ Control } & \multirow{2}{*}{ Total } & \multirow[b]{2}{*}{ Weight } & \multirow{2}{*}{$\begin{array}{l}\text { Mean Difference } \\
\text { IV. Fixed. } 95 \% \mathrm{Cl}\end{array}$} & \multirow{2}{*}{\multicolumn{3}{|c|}{$\begin{array}{l}\text { Mean Difference } \\
\text { IV. Fixed, 95\% Cl }\end{array}$}} & \\
\hline & Mean & SD & Total & Mean & SD & & & & & & & \\
\hline Gao et al.,2015 & 6.4 & 0.7 & 57 & 3.2 & 0.9 & 55 & $87.5 \%$ & $3.20[2.90,3.50]$ & & & & \\
\hline Hougraaf et al.,2012 & 4 & 2.5 & 9 & -1.7 & 10 & 4 & $0.1 \%$ & $5.70[-4.23,15.63]$ & & & & \\
\hline kim et al.,2018 & 9 & 4.7 & 14 & 5.3 & 2.6 & 12 & $1.0 \%$ & $3.70[0.83,6.57]$ & & & $\longrightarrow$ & \\
\hline Lee et al.,2014 & 1.9 & 2.7 & 30 & -0.5 & 1.8 & 28 & $5.7 \%$ & $2.40[1.23,3.57]$ & & & $\rightarrow$ & \\
\hline $\begin{array}{l}\text { Heterogeneity: } \mathrm{Chi}^{2}=4 \\
\text { Test for overall effect: } Z\end{array}$ & $\begin{array}{l}30, \mathrm{df}= \\
=21.92\end{array}$ & $\begin{array}{l}5(P=0 \\
P<0.0\end{array}$ & $\begin{array}{l}0.56) ; 1^{2} \\
00001)\end{array}$ & $=0 \%$ & & & & & $\begin{array}{l}-10 \\
\text { Favol }\end{array}$ & $\begin{array}{ll}-5 & 0 \\
S \text { [MSCS] }\end{array}$ & $\begin{array}{cc}5 & 5 \\
\text { Favours }\end{array}$ & $\begin{array}{c}10 \\
\text { control }\end{array}$ \\
\hline
\end{tabular}

\section{Figure 5}

The effect of MSCs Therapy on LVEF. Forest plot of the difference in change left ventricular ejection fraction from baseline to follow-up. 


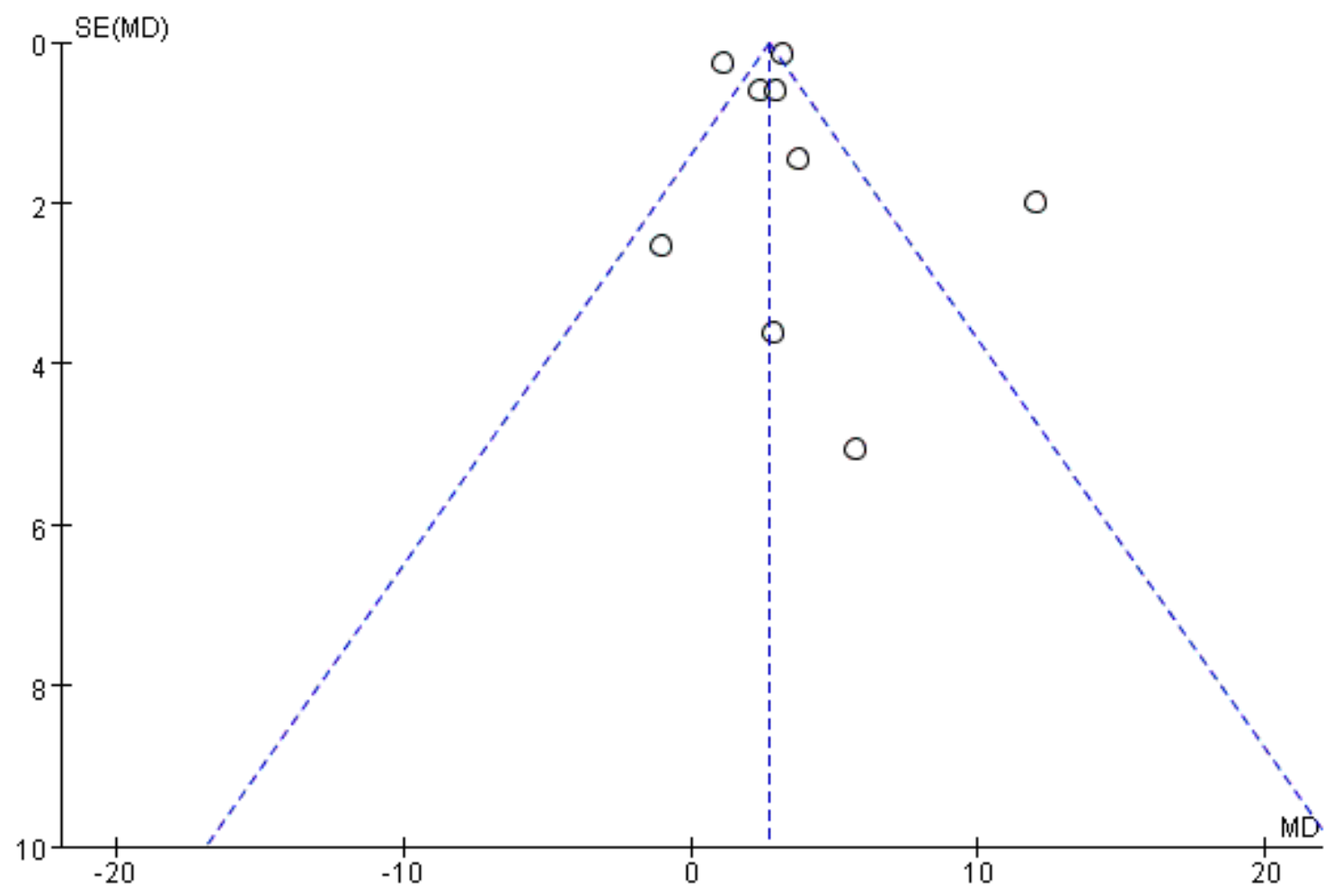

Figure 6

Funnel plot for change in overall effects of MSCs therapy on LVEF. 
a

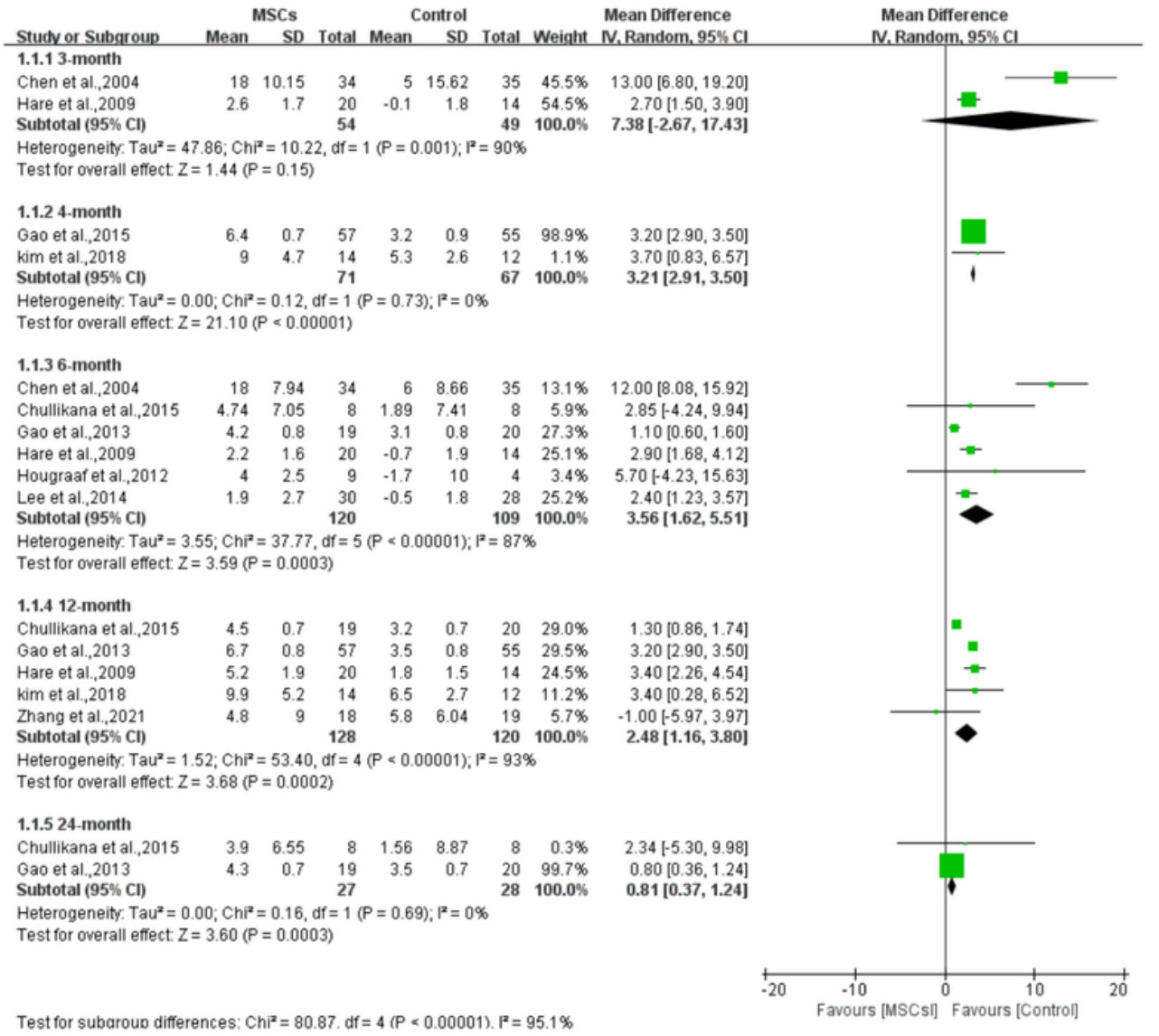

b

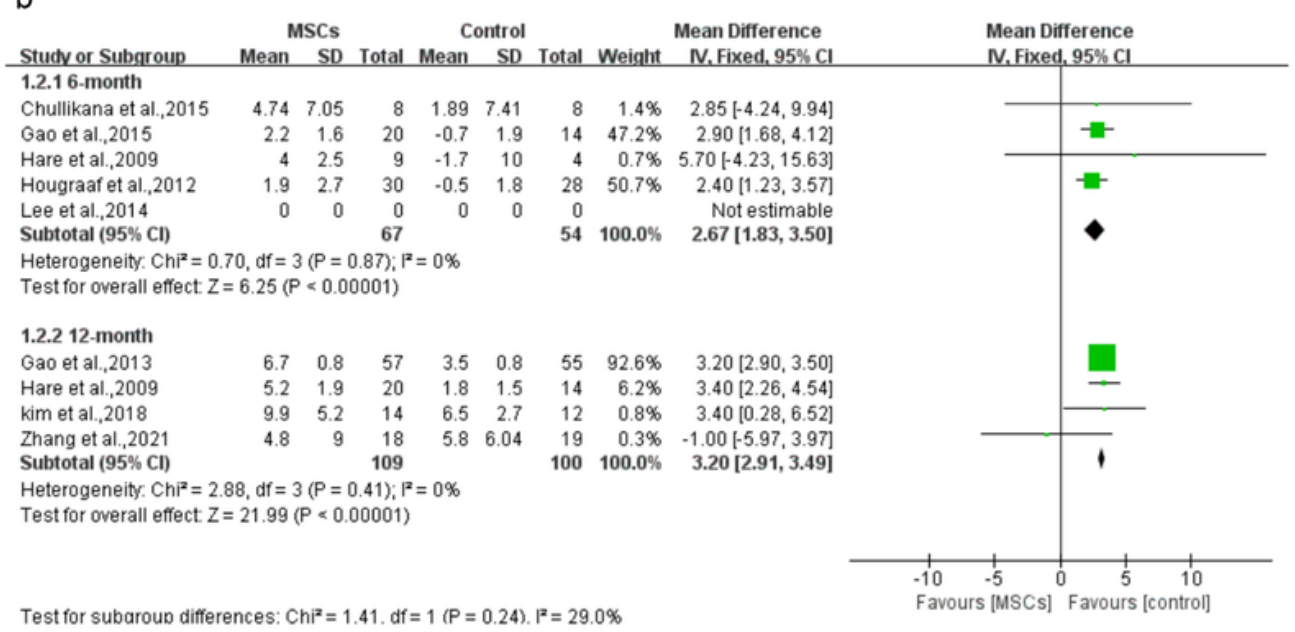

\section{Figure 7}

Forest plot of change in left ventricular ejection fraction of MSCs therapy at different time durations. MSCs mesenchymal stem cells; IV inverse variance; SD standard deviation; Cl confidence interval. 


\section{LVESV}

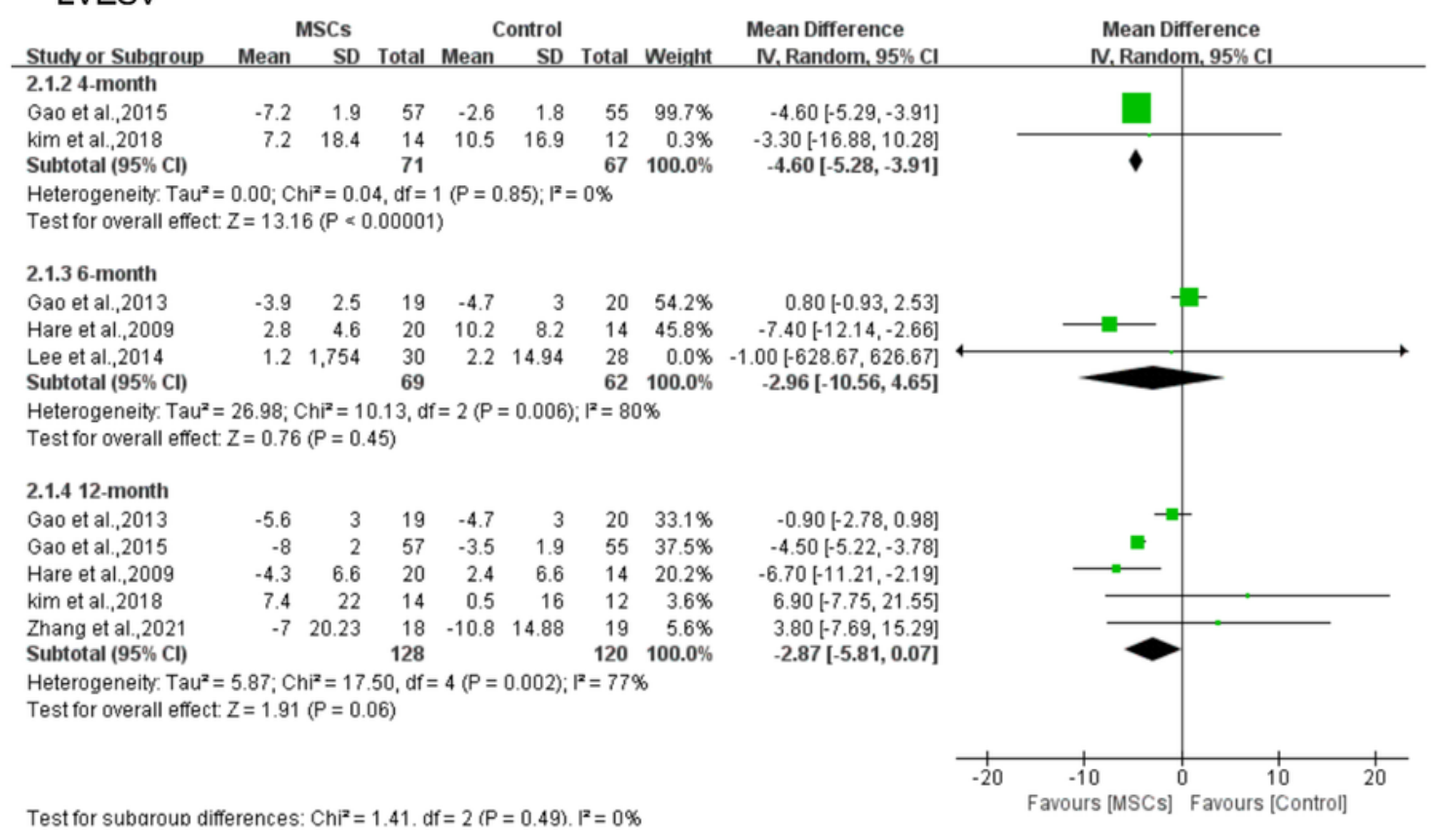

\section{LVEDV}

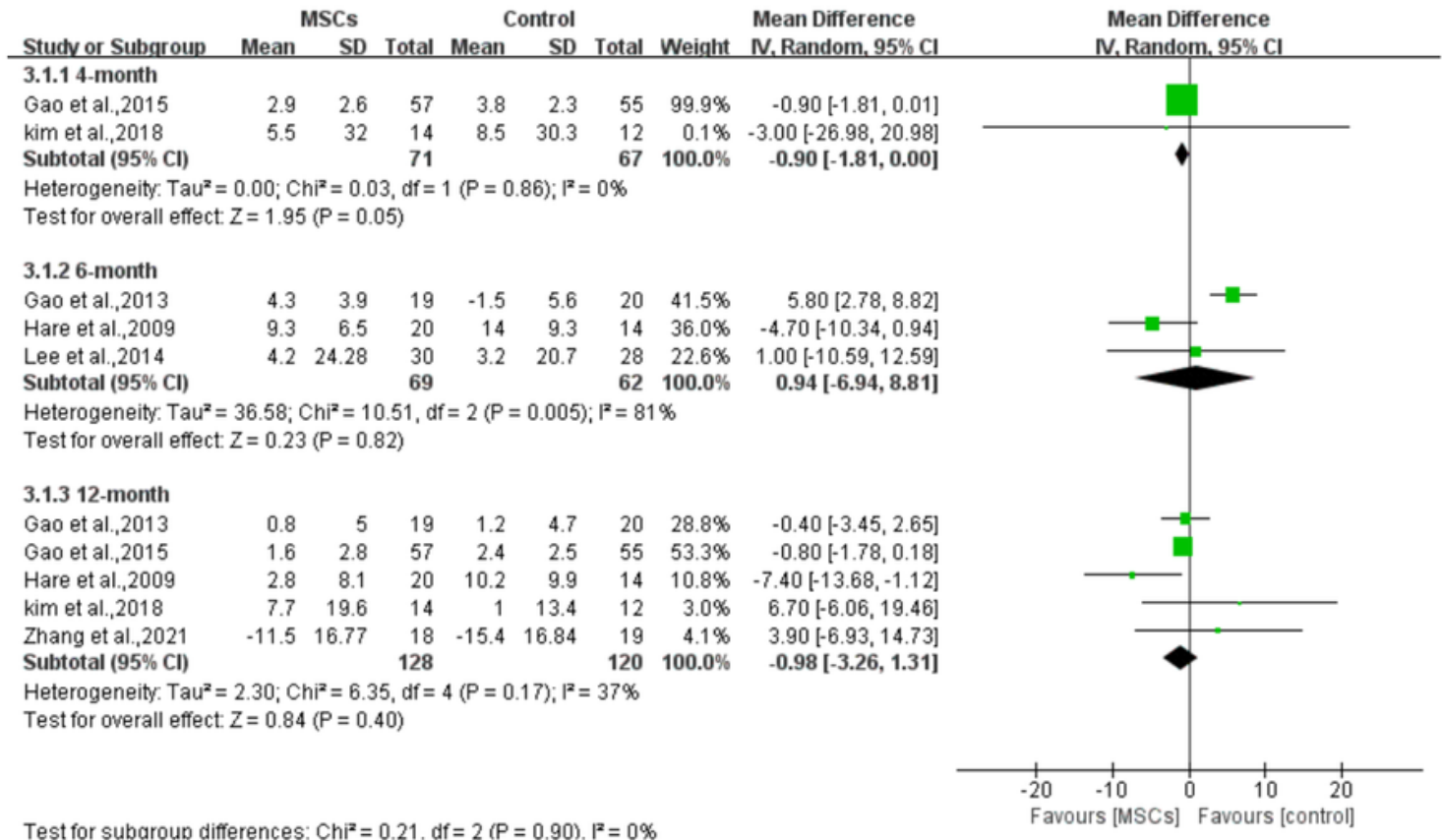

\section{Figure 8}

Forest plot of change in left ventricular end-systolic volume and end- diastolic volume of MSCs therapy at different time durations. MSCs mesenchymal stem cells; IV inverse variance; SD standard deviation; $\mathrm{Cl}$ confidence interval. 


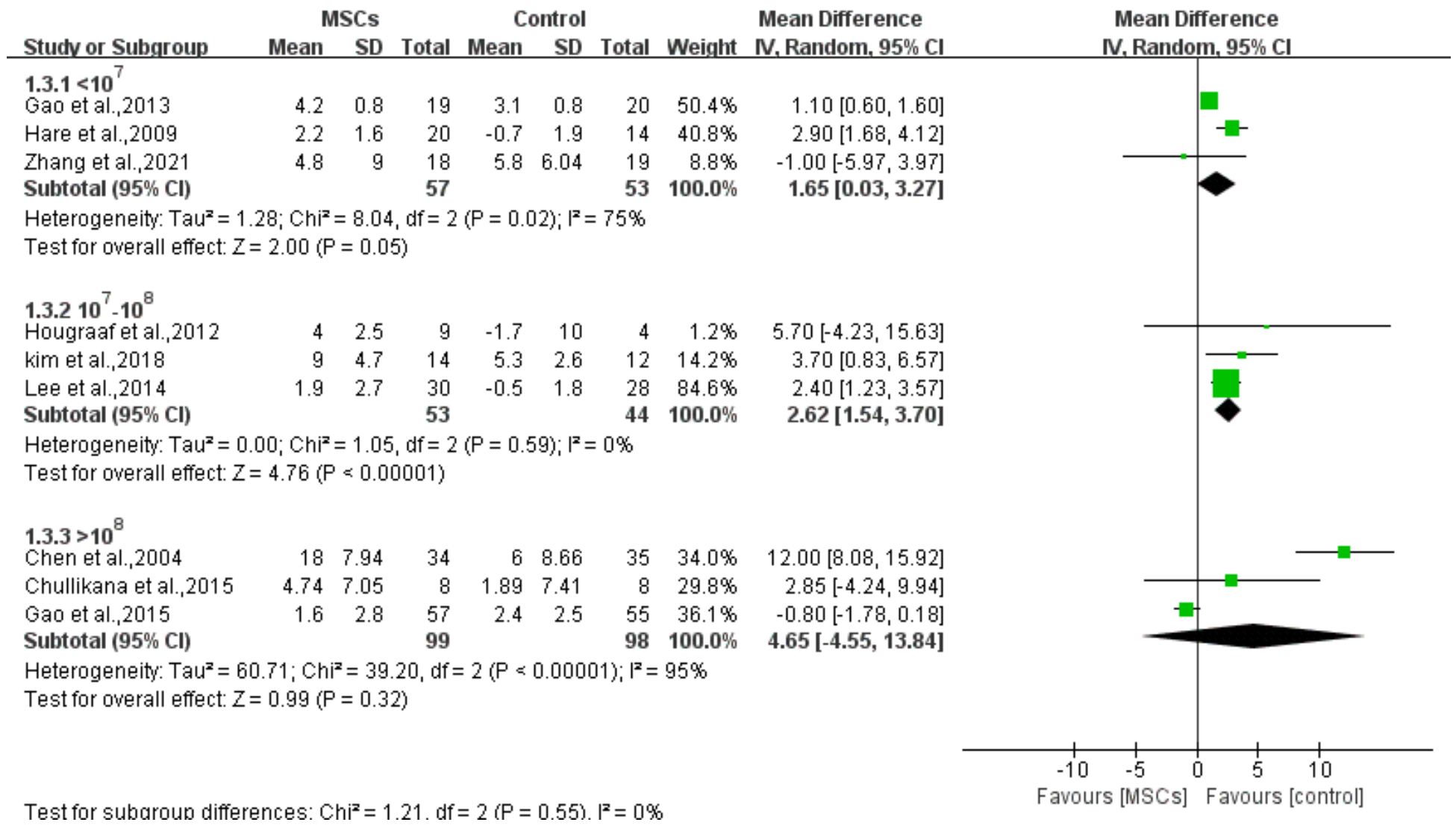

\section{Figure 9}

Forest plot of change in LVEF of MSCs therapy at different dose of cells infusion. MSCs mesenchymal stem cells; IV inverse variance; SD standard deviation; $\mathrm{Cl}$ confidence interval. 


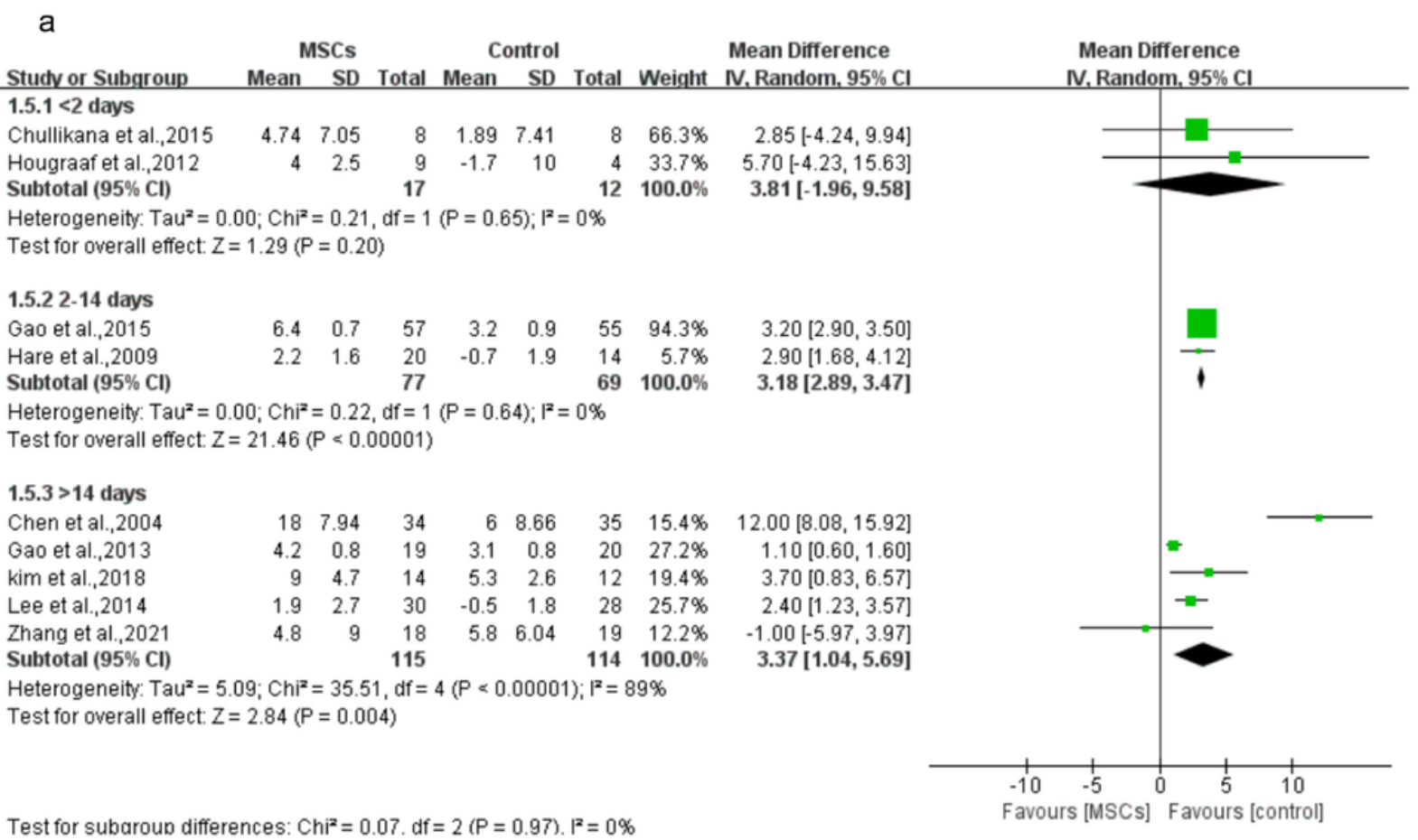

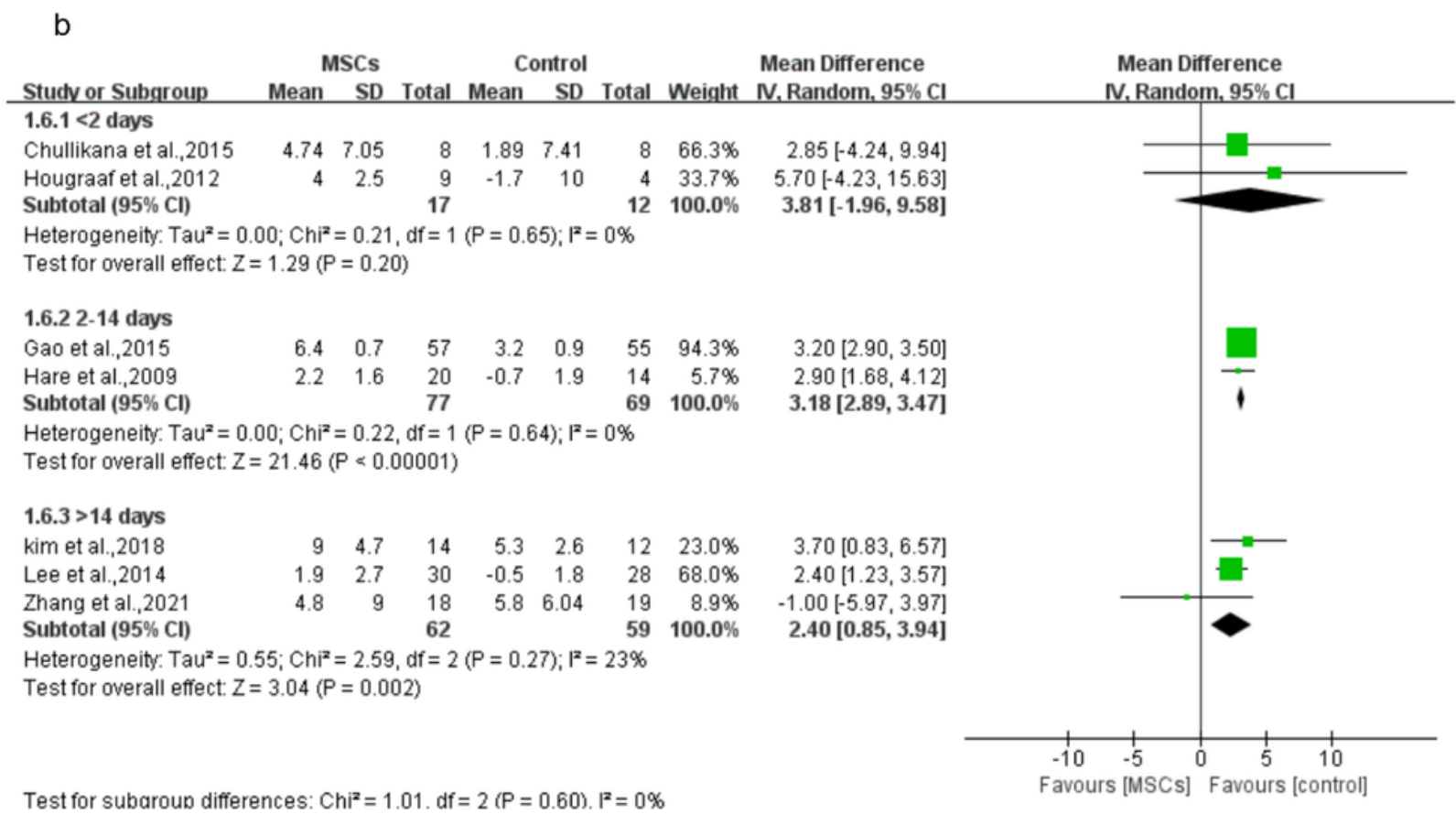

\section{Figure 10}

Forest plot of change in LVEF of MSCs therapy at different time of cells infusion. MSCs mesenchymal stem cells; IV inverse variance; SD standard deviation; Cl confidence interval. 
MSCs Control Odds Ratio Odds Ratio

Studv or Subgroup Events Total Events Total Weight M-H, Fixed, $95 \% \mathrm{Cl}$

Chullikana et al.,2015

$0 \quad 10$

$0 \quad 10$

Gao et al.,2013

Gao et al.,2015

Hare et al.,2009

Hougraaf et al.,2012

kim et al.,2018

Lee et al.,2014

Zhang et al.,2021

$\begin{array}{llll}2 & 21 & 0 & 21\end{array}$

$\begin{array}{llll}0 & 58 & 1 & 58\end{array}$

$\begin{array}{llll}0 & 58 & 1 & 58 \\ 0 & 39 & 0 & 21\end{array}$

$\begin{array}{lrrr}0 & 9 & 0 & 4\end{array}$

$\begin{array}{llll}0 & 14 & 0 & 12\end{array}$

$\begin{array}{llll}0 & 30 & 0 & 28\end{array}$

18

$18.6 \% 5.51$ (0.25, 122.08

$18.6 \% 5.51[0.25,122.08]$

$62.5 \%$

$0.33[0.01,8.21]$

Not estimable

Not estimable

Not estimable

Not estimable

Total $(95 \% \mathrm{CI})$

199

19

$18.9 \% \quad 3.34[0.13,87.52]$

Total events

Heterogeneity: $\mathrm{Chi}^{2}=1.71, \mathrm{df}=2(\mathrm{P}=0.42) ; \mathrm{I}^{2}=0 \%$

Test for overall effect: $Z=0.78(P=0.44)$

$173100.0 \% \quad 1.86[0.39,8.90]$

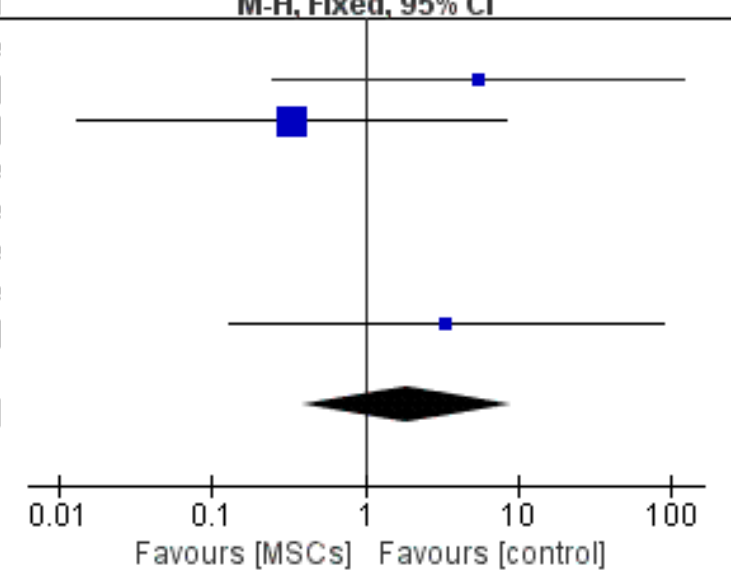

\section{Figure 11}

All-cause mortality of MSCs therapy on acute myocardial infarction.

\section{Supplementary Files}

This is a list of supplementary files associated with this preprint. Click to download.

- Literaturesearch.docx 